likely in the private than the public sector; lengths of stay in the two sectors were not appreciably different; and rates of bed occupancy were much lower in the private than the public sector. There is also a concern that fee for service care may increase discretionary and unnecessary clinical intervention. ${ }^{5}$ None the less, an element of competition between the public and private sectors might highlight areas in which further efficiencies might be made.

An expansion of private care has implications for resource allocation and planning within the NHS. Nicholl et al suggest that resource allocation within the NHS should take account of geographical variation in the provision of private care. This may have some merit in terms of equity. It would, however, establish the practice of private funding as a substitute for NHS funding, and it might lead to a downward spiral of standards in the NHS - reduced NHS funding leading to lower standards of care, leading to more people seeking private care, leading to further reductions in NHS funding, and so on.

Health service planners will need to decide whether local services should be planned for the total care required for their population or whether plans should include estimates of care that may be given in the private sector. This would require more information than that currently available on the private sector. The difference between the approaches in the volume of services planned may be considerable. More generally, we must formulate our views on the loss of part of the NHS "market" to the private sector. Is the loss a welcome relief for a hard pressed service or should the NHS try to recapture it?

MICHAEL GOLDACRE

Lecturer in Community Medicine,

University of Oxford,

Department of Community Medicine and General Practice,

Radcliffe Infirmary, Oxford OX2 6HE

Department of Health and Social Security. Medical manpower: the next twenty years. London: HMSO, 1978.

2 Parkhouse J. Medical manpower in Britain. Edinburgh: Churchill Livingstone, 1979:1-49. Department of Health and Social Security. Hospital medical staffing: achiering a bulance. London: DHSS, 1986

4 Conroy M, Stidston M. 2001: The black hole. An examination of labour market trends in relation to the National Health Service. Oxford: South West Thames and Oxford Regional Health Authorities, 1988

5 McLachlan G, Maynard A, eds. The public/private mix for health: the relevance and effects of change. London: Nuffield Provincial Hospitals Trust, 1982.

6 Peet J. Healthy competition: how to improve the NHS. London: Centre for Policy Studies, 1987.

7 Letwin O, Redwood J. Britain's biggest enterprise: ideas for radical reform of the National Health Service. London: Centre for Policy Studies, 1988.

8 Willetts D, Goldsmith M. A mixed economy for health care: more spending, same caxes. London: Centre for Policy-Studies, 1988

Cook R. Life begins at 40: in defence of the National Health Service. London: Fabian Society, 1988. Cook R. Life begins at
(Fabian Tract 529. .

10 National Association of Health Authorities. The nation's health: a way forward. Birmingham: NAHA, 1988.

11 British Medical Association. Evidence to the government internal review of the National Health Service. Br Med f 1988;296:1411-8.

12 Office of Health Economics. Compendium of health statistics. 6th ed. Part 2. London: OHE, 1987:7-11.

\title{
Control of hospital infection
}

\section{Enhancing present arrangements}

Patients in hospital are particularly prone to infection, which threatens the success of their treatment and even their lives. In 1979 almost a fifth of the 18186 patients surveyed in 43 British hospitals had infections, half of which were acquired in hospital. ${ }^{\prime}$ The estimated yearly cost for 1986 in England was $£ 111 \mathrm{~m}$, or a loss of 950000 bed days.

Over 10 years ago it was confirmed in the United States that surveillance, control methods, and an infection control team reduce infection rates in hospitals. ${ }^{2}$ Although most hospital acquired infection is non-epidemic, recent poorly controlled outbreaks - such as that caused by salmonella at Wakefield ${ }^{3}-$ have focused the British Department of Health's attention on the arrangements for curtailing hospital infection. Thus a hospital infection working group, chaired by Professor Mary Cooke, has recently published its clear and sensible report Hospital Infection Control-Guidance on the Control of Infection in Hospitals. ${ }^{+}$The government now wants health authorities to draw on the Cooke report and ensure that they have clear management arrangements for controlling hospital infection. Existing arrangements, despite their success in most British hospitals ${ }^{56}$ received scant mention in the chief medical officer's 1988 report Public Health in England.

The Cooke report is unambiguous that it is the district general manager, advised by the district's hospital infection control committee, who is responsible to the health authority for setting up, maintaining, and funding the arrangements for infection control in districts, units, and hospitals: "the issues of hospital infection are sufficiently clear to require the district hospital infection control committee to report directly through the district general manager to the district health authority." This committee, the report says, should include the infection control doctor (presently known as the control of infection officer); the medical microbiologist if the infection control doctor is not one; the infection control nurse; a surgeon; a physician representing the senior medical staff; a representative of the chief nursing adviser; the occupational health physician; the district medical officer; the medical officer of environmental health; the general manager; and, when he or she exists, the infectious diseases physician. Others may be co-opted.

It is the skill and experience of the infection control doctor that are crucial to controlling hospital infection. He or she is directly accountable to the unit manager and the district general manager, is responsible for the infection control nurse, and leads the infection control team (infection control doctor, infection control nurse, and the district general manager or a representative). The team conducts surveillance, initiates the response to outbreaks, and formulates and implements the policies approved by the infection control committee that have the approval and authority of the district general manager. The infection control team provides day to day monitoring and advice and implementation of policies, including isolation of patients, use of antimicrobials, infection hazards, disinfection, sterilisation, immunisation, staff education, and resource allocation. The chief medical officer acknowledges the "invaluable contribution of microbiologists to hospital infection control," and the Cooke report is clear that the infection control doctor should be a consultant with training, skill, and experience in all aspects of infection control and should have ready access to laboratory facilities. This person is likely to be the local medical microbiologist. Indeed, a survey of the Hospital Infection Society in 1986 showed that $98 \%$ of all health authorities in England and Wales already have control of infection officers; four fifths were consultant medical microbiologists who had received higher training in hospital infection control. ${ }^{8}$ 
These arrangements for skill, executive authority, and accountability, which may serve as a model for other countries, now need urgent enhancement in the light of the two new reports. The increasing recognition and demands on the infection control doctor may make it impossible for a single handed microbiologist in a district general hospital to provide a 24 hour service, which may be a further reason for implementing the Royal College of Pathologists' recommendation for a second consultant microbiologist in larger hospitals. Similarly, a single infection control nurse may no longer be adequate for districts with 750 or 1000 beds. The requirement in the United States is for one nurse for every 250 beds.

The chief medical officer proposed in his report a new post of district control of infection officer, whose job is distinct from the infection control doctor and is "to coordinate the work of control of infection between hospitals, and between hospitals and the community." The district control of infection officer would be accountable managerially to the newly proposed director of public health, who is in turn accountable to the district general manager. As the Cooke report points out, "the role of the infection control doctor as the person previously responsible for infection control within the hospital remains unaffected by the chief medical officer's report." How many infection control doctors will wish, given the resources, to extend their skill into the community and take on the additional function of the district control of infection officer remains to be seen.

Professor of Medical Microbiology,

MARK CASEWELL

King's College School of Medicine and Dentistry,

London SE5 8RX

1 Meers PD, Ayliffe GAJ, Emmerson AM, et al. Report on the National Survey of Infection in Hospitals 1980. 7 Hosp Infect 1981; 2(suppl 1):13-7.

2 Haley RW, Culver DH, White JW, et al. The efficacy of infection surveillance and control programs in preventing nosocomial infection in US hospitals. Am f Epidemiol 1985;121:182-205.

Department of Health and Social Security. The report of the committee of inquiry into an outbreak of food poisoning at Stanley Royd Hospital. London: HMSO, 1986. (CM 4190.$)$

4 Joint Department of Health and Social Security and Public Health Laboratory Service Hospital Infection Working Group. Hospital infection control-guidance on the control of infection in hospitals. London: DHSS, 1988. Cooke report.)

5 Phillips I, Eykyn S. Acheson: a missed opportunity for the new public health. Br Med J 1988;296:640-1.

Ayliffe GAJ. Acheson: a missed opportunity for the new public health. Br Med f 1988:296:641.

7 Committee of Inquiry Into the Future Development of the Public Health Function. Public Health in England. London: HMSO 1988. (CM 289.) (Acheson report.)

8 Howard AJ. Infection control organization in hospitals in England and Wales, 1986. Report of a survey undertaken by a Hospital Infection Society Working Party. J Hosp Infect 1988;11:183-91.

\section{Amblyopia}

\section{Neither screening nor treatment is satisfactory}

Amblyopia, defective visual acuity in a healthy eye that cannot be made normal with spectacles, is rarely due to congenital abnormalities but is mostly associated with squint or an abnormal refraction, or both. The traditional treatment with spectacles or occlusion does not produce satisfactory long term results, ${ }^{\prime}$ probably because treatment is started too late. Hence there have been many pleas for more rapid referral of those who squint and earlier identification of "straight eyed" amblyopic children before they start school, when they are screened. Nevertheless, the school screening programme for vision is not satisfactory, ${ }^{23}$ and an earlier screening programme at the age of $3 \frac{1 / 2}{2}$ was no more effective in producing better results. ${ }^{+}$

We do not fully understand how amblyopia develops. Squint has always been thought to cause amblyopia, and it has long been accepted that an early onset of the squint or any delay in treating it leads to more severe amblyopia. Nevertheless, these suggestions have never been confirmed (R M Ingram et al, unpublished data). ${ }^{6}$ Anisometropia, an undefined difference between refraction of the two eyes, is the abnormality most frequently associated with amblyopia, particularly in "straight eyed" children. Most believe that anisometropia causes the amblyopia; but why is it not the other way round? We do not know.

Though few question the use of occluding one eye in treatment, even 20 years ago Tour observed that "after using occlusion for two centuries, we still do not know which eye to occlude, with what or for how long." ${ }^{8}$ Certainly the value of occlusion has never been assessed scientifically. It is highly successful in some cases, but we have no means of predicting which ones. All too often the visual acuity of the amblyopic eye improves only to fall again when occlusion is stopped. But any attempt of a scientific assessment of occlusion will be difficult on ethical grounds.'

Severe amblyopia (6/24 or less) that persists after occlusion is associated with abnormally hypermetropic (or rarely myopic) defects in infancy. ${ }^{9}$ Unfortunately correction of these abnormalities with spectacles from the age of 1 year did not alter the subsequent incidence of squint or severe amblyopia. ${ }^{10}$ Possibly, however, treatment from the age of 6 months might reduce the incidence of severe amblyopia but not that of squint (R M Ingram et al, unpublished data).

So the conclusion must be the familiar one that further research into the natural course of amblyopia is required before we can suggest any new screening programme for detecting it or any new form of treatment. But at the very least, failure to observe the rules ${ }^{11}$ for new screening tests will postpone research on more productive lines. ${ }^{12}$ Once a screening programme has been accepted by both the public and clinicians it is difficult to re-evaluate it. Another aspect that needs agreement is the level of amblyopia that needs treatment, for, though this may not impede education,,$^{13}$ it may prevent sufferers from entering some occupations.

R M INGRAM

Consultant Ophthalmologist,

Kettering and District General Hospital,

Kettering,

Northamptonshire NN16 8UZ

Ingram RM. Amblyopia: the need for a new approach? Brf Ophthalmol 1979;63:236-7

Ingram RM. Review of children referred from the school vision screening programme in Kettering during the years 1976-8. Br.Med $\mathcal{F}$ (in press).

Stewart-Brown SL, Haslum MN. Screening of vision in school: could we do better by doing less? Br.Med f 1988;297:1111-3.

4 Ingram RM, Holland WW, Walker C, Wilson JM, Arnold PE, Dally S. Screening for visual defects in pre-school children. Brf Ophthalmol 1986;70:16-21.

Worth C. Squint: its causes, pathologv and treatment. London: John Bale Sons and Danielsson, 1903:76-7

6 Costenbader F, Bair D, McPhail A. Vision in strabismus. Arch Ophthalmol 1948:40:+38-53.

7 Lang J. Microtropia. Arch Ophthalmol 1969:81:758-62.

7our RL. Annual review of strabismus Arch Ophthalmol 1966:76:293.

9 Ingram RM, Walker C, Wilson JM, Arnold PE, Dally S. Prediction . Walker C, Wilson JM, Arnold PE, Dally S. Prediction of amblyopia and squint by means of refraction at age 1 vear. $\mathrm{Br}$ f Ophthalmol 1986;70:12-5.

10 Ingram RM, Walker C, Wilson JM, Arnold PE, Dally S. A first attempt to prevent amblyopia and squint by spectacle correction of abnormal refractions from age 1 year. $\mathrm{Br} \mathcal{7}$ Ophthalmol 1985:69:851-3.

11 Wilson JMG, Jungner G. Principles and practices of screening for disease. Geneva: W'orld Health Organisation, 1968. (Public Health Paper No 34.)

12 Sackett DL, Holland WW. Controversy in the detection of disease. Lancet 1975;ii:357-9.

13 Stewart-Brown S, Haslum $M N$, Butler N. Educational attainment of 10 year old children with treated and untreated visual defects. Dev. Med Child Neurol 1985;27:504-13. 